\title{
Managerial Competences of Headmaster in Improving the Quality of Library
}

\author{
Tapsila $^{1 *}$, Edi Harapan ${ }^{2}$, Rohana $^{2}$ \\ ${ }^{1}$ SMA Negeri 1 Sekayu, South of Sumatera, Indonesia \\ ${ }^{2}$ Universitas PGRI Palembang, Indonesia \\ *Corresponding author. Email: tapsila2017@gmail.com
}

\begin{abstract}
This study aims to identify and describe the Principal's Managerial Competence in Improving Library Quality. The research was conducted at SMA Negeri 1 Sekayu. This type of research is descriptive qualitative research. Data collection tools use documentation, interviews, observation. The data analysis technique used a qualitative descriptive analysis technique. The results of the study stated that 1) the principal's leadership in improving the quality of the library was pursued by the formulation of library quality improvement programs, maximizing library services, maximizing the role of library human resources, and maximizing library infrastructure facilities; 2) The constraints faced are the planning for the fulfillment of public school library facilities following the rules set by the government, the implementation of the library administration system is still managed manually, the lack of training to increase library management capacity, and the limited school budget; 3) The solution taken by the principal in facing obstacles was taken by inviting the school committee to take an active role in improving the quality of the library, providing training and encouraging all school members to take part in every activity.
\end{abstract}

Keywords: Managerial Competence, Library, Quality

\section{INTRODUCTION}

This research is motivated by the importance of improving the quality of education through school library management. In Law No. 202013 it is also explained that schools must prepare learning resources both in terms of facilities and infrastructure. Bramasta and Irawan [1] argued that one of the facilities and infrastructure that could support the improvement of the quality of education was a facility that supported the teaching and learning process. The facilities and infrastructure that must be fulfilled include the school library. The library is the main yardstick in determining the improvement in the quality and quantity of both schools and students. Zakiyah [2] stated that the library space is something that must be owned by schools.

Library has an important role in improving the quality of education. As a learning tool that provides various sources of information that support the learning process [3]. School library can be a driving force to realize the maximum teaching and learning process and play a very important role of education in schools [4].
The role and purpose of the library is as a vehicle to educate the nation in order to achieve an educated society [5].

So, we need a good management system in managing the library. It means that library management must be prepared and in line with the school's vision and mission [6].

Lasa [7] states that a library can be used as: 1) a source of material for comparison with what is already known, and to find out a branch of science and its correct understanding; 2) sources to deepen a branch of science, especially in the implementation of education; 3 ) sources of material to identify and follow the pace of scientific and cultural development and can also be used as reference materials; 4) a source of material for creative and appreciation exercises, as well as a means to arouse and foster children's reading intentions and to solve problems at hand; 5) as a training ground for students to be able to use the library collections properly.

Therefore, library services in schools must be carried out professionally, namely by prioritizing the values of accuracy and satisfaction served [8]. 
Therefore, we need the ability of the principal who is able to manage the library optimally. Library management can be defined as library management using management principles and management theories [9]. In essence, management includes planning, organizing, implementing and controlling to achieve goals by utilizing several resources so that they have added value. Murniati and Usman [10] stated that management is an activity to regulate various resources, both human and material, in order to carry out various activities of an organization to achieve optimal goals.

To carry out their duties properly, the principal should understand, master and be able to carry out activities related to their duties. A well-managed library is an effort to create qualified education. Sukmadinata [11] states that school quality is influenced by a qualified education process with some supporting factors, facilities and infrastructure, and proper management. Fani [12] stated that infrastructure affects the quality of education.

Thus, improving the quality of the school library is strongly influenced by the ability to manage the school by principals because school leadership is one of the factors that determine the effectiveness of the school.

\section{METHODS}

This research was conducted at SMA Negeri 1, Sekayu District, Musi Banyuasin Regency, South Sumatra Province, Indonesia. Data collection tools used are interviews, documentation and observation. The research sources were the teacher, the library head and staff as well as the principal of SMA Negeri 1 Sekayu.

Data analysis used a descriptive qualitative approach which included the process of data reduction, data presentation and drawing conclusions to obtain a general and comprehensive picture of the research object.

\section{RESULTS AND DISCUSSION}

\section{1) Formulation of Library Quality Improvement Program}

The formulation of library quality improvement carried out by the principal begun with planning for improving the quality of the library at SMA Negeri 1 Sekayu designed to support school programs, namely building a school literacy culture which aims to increase students' abilities in reading, writing and communication skills as a whole which can impact on development character and students' skill. Library planning consists of planning the book supply, providing infrastructure, arrangement of equipment in the library, archiving, and planning for human resource development. These activities are carried out through the School Work and Budget Plan (RKAS-1) and the
School Activity and Budget Plan (RKAS-2). RKAS-1 is also known as the Strategic Plan (RENSTRA).

Furthermore, formulating regulations in the form of rules, restrictions and sanctions that must be obeyed by library visitors means that visitors can use the library properly.

Technical planning for improving the quality of the library at SMA Negeri 1 Sekayu is designed in accordance with the RKS through various activities including planning of book supply, providing of infrastructure, arrangement of equipment in the library, and human resource development. So that the library quality improvement program for SMA Negeri 1 Sekayu can run effectively. The planning involved all school components including the School Committee and was known and approved by the Head of the South Sumatra Provincial Education Office. The involvement of school components, including teachers, education personnel and school committees, is carried out by providing opportunities for all components to be involved in efforts to improve the quality of the library.

The involvement of the School Committee as a consideration provider is given the opportunity to provide input and considerations in terms of the draft school income and expenditure budget (RAPBS). Santoso stated that the School Committee's efforts to improve the empowerment of school libraries can be done through: 1) The role of the School Committee as an advisor, 2) Role of the School Committee as a supporter (supporting); 3) Role of the School Committee as a controller, and 4) The role of the school committee as a mediator between the government (executive) and the community in education units [13].

The involvement of the Education Office is certainly carried out because in general the stages of planning for the fulfillment of facilities, especially public of school libraries, follow the rules set by the government.

\section{2) Implementation of Library Quality Improvement Program}

Improving the quality of the library is carried out in three parts, namely:

\section{a) Maximizing Library Services}

Improving library quality through efforts to maximize the role of library human resources is pursued by maximizing library services by efforts to maximize existing resources in managing the library by providing services to visitors for six days and every day for five hours starting at 07.00-12.00. Improve circulation services and reference services through the mandatory library visit program one lesson hour per class per week. To find out about activities in library management Librarians make monthly reports on activities related to the intensity of students reading books, going in and out of books and administrative systems related to libraries 
such as student report books and library cards then build a comfortable atmosphere in the library environment.

\section{b) Maximizing the role of Library's Human Resources}

The Implementation of improving library quality is that to maximize the role of library human resources. It can be achieved by standardizing the number of library personnel owned namely assigning three library staffs consisting of the head of the library and 2 library administration staffs. Carry out a clear division of tasks by the principal, so that there is no overlapping of responsibilities and there is also no vacancy in the person in charge. Form the mindset of all school members to build commitment and awareness to participate in maximizing efforts to improve library quality. Providing opportunities for library managers to take part in continuous training. In addition, the principal also always carries out such training which is carried out regularly either by controlling it daily, weekly, monthly, and annual reports of the library.

\section{c) Maximizing Library Facilities}

Implementation of improving the quality of the library through efforts to maximize library infrastructure is pursued by adding book collection in the library. Try to provide all library infrastructure facilities in accordance with the National Standard Guidelines for School Libraries. Conditioning a comfortable atmosphere in the library by placing the library in a comfortable room with good air circulation where the air ventilation is quite a lot and good lighting makes the library comfortable for students to do reading activities and carry out activities in the library. Kodri, Fahmi \& Haqq [14] stated that the efforts made by library managers to increase students' interest in reading were by collaborating with teachers in schools, providing adequate collections according to student needs and adequate facilities for the needs and comfortable of students who visit the library.

\section{3) Obstacles Encountered}

The obstacle faced at the planning stage is the planning for the fulfillment of public of school library facilities following the rules set by the government in this case the provincial government through RKAS. So, the school follows the rules set by the provincial government. At the implementation stage, it is constrained by the library administration system which is still managed manually. Then the lack of training to increase the ability of library management held both at school and outside the school has limited budget and difficulties in bringing in experts who can provide training as well as provide guidance to library managers. In line with Irawati's statement that the principal is not optimally managing school libraries due to: school library services have not satisfied library service users, there is no adequate library management system, students have not utilized the library maximally, have not been well organized and organized school libraries are there is and lack of supervision from the principal of the school library [15].

\section{4) Solutions Taken in Addressing Constraints}

The solution taken was to invite the school committee to take an active role in improving the quality of the library. Providing training and encouraging library commitment managers to improve their competence through reading articles and reading library management modules and encouraging all school stakeholders to take part in library quality improvement activities. As stated by Rohmah [16] that the commitment of school leaders and library leaders in terms of library quality assurance can also be seen from the leadership's commitment in controlling, directing and organizing activities that take place at the library by mobilizing all available strengths and potential.

\section{CONCLUSION}

Based on the results of research and discussion, it can be concluded that: 1) the principal's leadership in improving the quality of the library is pursued by the formulation of a library quality improvement program, maximizing library services, maximizing the role of library human resources, and maximizing library infrastructure facilities; 2) the constraints faced are the planning for the fulfillment of public school library facilities following the rules set by the government, the implementation of the library administration system is still managed manually, the lack of training to increase library management capacity, and the limited school budget, and 3) the solution taken by the principal in facing obstacles was taken by inviting the school committee to take an active role in improving the quality of the library, providing training and encouraging all school members to take part in every activity.

\section{ACKNOWLEDGMENT}

Our deepest gratitude goes to Teachers in SMA Negeri 1 Sekayu, Chancellor of Palembang PGRI University, Director of the Postgraduate Program of PGRI Palembang University and the Education Management Study Program of PGRI Palembang University, who have supported us in doing this extraordinary thing. This project is funded independently. We also want to thank our Education Management friends who helped us a lot in a short time frame to complete this project.

\section{REFERENCES}

[1] Bramasta, D., \& Irawan, D. (2018). Persebaran Sarana dan Prasarana Perpustakaan Sekolah Dasar Berbasis Sistem Informasi Geografis [Distribution of Elementary School Library Facilities and 
Infrastructure Based on Geographical Information Systems]. Khazanah Pendidikan 11, no. 1.

[2] Zakiyah, E. (2017). Implementasi Arsip Elektronik Dalam Mendukung Good Goverment. [Implementation of Electronic Archives in Support of Good Government]. Shaut Al-Maktabah: Jurnal Perpustakaan, Arsip dan Dokumentasi 9, no. 2, 183-190.

[3] Supriati, E. (2018). Peran Perpustakaan dalam Meningkatkan Mutu Pendidikan di Universitas Muhammadiyah PonorogoThe Role of Libraries in Improving the Quality of Education at Muhammadiyah Ponorogo University. Muslim Heritage 2, no. 2, 217-234.

[4] Suhardi, D. (2011). Peranan Manajemen Perpustakaan Sekolah Dalam Mendukung Tujuan Sekolah [The Role of School Library Management in Supporting School Goals]. Edulib 1, no. 1 .

[5] Sinaga, D. (2011). Mengelola perpustakaan sekolah [Manage the school library]. Bandung: Bejana.

[6] Gautama, M. G. A. (2017). Penerapan manajemen risiko berbasis ISO 31000 pada pencapaian target produksi di PT. Tridaya Dimas Aditama [The application of risk management based on ISO 31000 in achieving production targets at PT. Tridaya Dimas Aditama]. Bandung: UnPar.

[7] Hs, L. (2013). Manajemen Perpustakaan Sekolah/Madrasah [School / Madrasah Library Management]. Yogyakarta: Ombak.

[8] Surachman, A. (2012). Pustakawan asia tenggara menghadapi globalisasi dan pasar bebas [Southeast Asian librarians face globalization and free markets]. Media Pustakawan, 19(1).

[9] Sutarno. (2006). Manajemen perpustakaan: suatu pendekatan praktik [Library management: a practical approach]. Jakarta: Sagung Seto.

[10] Nurmasyitah, N., Murniati, A. R., \& Usman, N. (2015). Implementasi Manajemen Stratejik Dalam Meningkatkan Kinerja Guru Pada Sekolah Menengah Kejuruan Negeri 3 Lhokseumawe [Implementation of Strategic Management in Improving Teacher Performance in State Vocational High School 3 Lhokseumawe]. Jurnal Administrasi Pendidikan Program Pascasarjana Unsyiah 3, no. 2: 94530.

[11] Sukmadinata, N. S. (2006). Pengendalian mutu pendidikan sekolah menengah (konsep, Prinsip, dan instrument) [Control of the quality of secondary school education (concepts, principles, and instruments)]. Bandung: PT Refika Aditama.

[12] Fani, Y. Y. (2016). Analisis Faktor-Faktor Yang Mempengaruhi Mutu Pendidikan Sekolah Menengah Kejuruan Di Kabupaten Sijunjung
[Analysis of Factors Affecting the Quality of Vocational High School Education in Sijunjung Regency]. PhD diss., Universitas Andalas.

[13] Santoso, I. (2013). Peran Komite Sekolah Dalam Pelaksanaan Manajemen Berbasis Sekolah Di SMP Negeri 2 Wonogiri [The Role of the School Committee in Implementing School-Based Management at SMP Negeri 2 Wonogiri]. PhD diss., Universitas Muhammadiyah Surakarta.

[14] Kodri, M., Fahmi., \& Haqq, A. (2019). Peran Pengelola Perpustakaan Dalam Meningkatkan Minat Baca Siswa Melalui Pemanfaatan Perpustakaan SMA N surulangun kab. Musi rawas utara [The Role of Library Managers in Increasing Student Reading Interest through the Utilization of the Library of SMA N Surulangun, Musi Rawas Utara Regency]. PhD diss., UIN Sulthan Thaha Saifuddin Jambi.

[15] Irawati, I., \& Darmaiwan, H. (2014). Perluasan dan penyesuaian notasi DDC untuk wilayah Indonesia [Expansion and adjustment of DDC notation for Indonesian territory]. Jakarta: Bumi Aksara.

[16] Rohmah, S. (2015). Penjaminan Mutu Pengelolaan Perpustakaan Sekolah [Quality Assurance of School Library Management]. Manajer Pendidikan 9, no. 5 . 